\title{
Identification and assessment of virulence of a natural reassortant of infectious bursal disease virus
}

\author{
Anna Pikuła ${ }^{1 *} \mathbb{D}$, Anna Lisowska ${ }^{1}$, Agnieszka Jasik² and Krzysztof Śmietanka ${ }^{1}$
}

\begin{abstract}
Infectious bursal disease virus (IBDV) is one of the most important immunosuppressive viral agents in poultry production. Prophylactic vaccinations of chicken flocks are the primary tool for disease control. Widely used immunoprophylaxis can, however, provide high pressure which contributes to the genetic diversification of circulating viruses, e.g. through reassortment of genome segments. We report the genetic and phenotypic characterization of a field reassortant IBDV (designated as Bpop/03) that acquired segment A from very virulent IBDV and segment B from classical attenuated D78-like IBDV. Despite the mosaic genetic make-up, the virus caused high mortality (80\%) in experimentally infected SPF chickens and induced lesions typical of the acute form of IBD. The in vivo study results are in contrast with the foregoing experimental investigations in which the natural reassortants exhibited an intermediate pathotype, and underline the complex nature of IBDV virulence.
\end{abstract}

\section{Introduction}

Infectious bursal disease virus (IBDV) is a doublestranded RNA virus which belongs to the Avibirnavirus genus, Birnaviridae family. The virus possesses a bisegmented genome (segments $\mathrm{A}$ and $\mathrm{B}$ ) within a nonenveloped icosahedral capsid and is the causative agent of an immunosuppressive disease of young chickens [1]. It is commonplace in nature that viruses with segmented genomes may exchange genetic material if they infect one cell at the same time. Natural reassortants of IBDV have already been reported from Asia [2, 3], South America [4], North America [5], Africa [6, 7] and Europe [8].

The genome of IBDV encodes for 5 viral proteins. VP2 is the major structural viral protein that builds the viral capsid [9] and contains an antigenic domain responsible for inducing secretion of neutralization antibodies [10]. The IBDV encodes its own RNA-dependent RNA polymerase designated VP1 that is responsible for the genome replication, transcription [11] and probably translation of virus protein [12]. The VP2, VP1 and another structural

\footnotetext{
*Correspondence: anna.pikula@piwet.pulawy.pl

1 Department of Poultry Diseases, National Veterinary Research Institute,

Al. Partyzantow 57, 24-100 Pulawy, Poland

Full list of author information is available at the end of the article
}

protein VP3 together play a crucial role in the morphogenesis and encapsidation of the viral genome [13]. In turn, the VP4 protein is a viral protease [14] that effects post-translational cleavage of the polyprotein (VP2VP4-VP3) and takes part in the maturing of the VP2 peptide [15]. VP5 is a non-structural protein that cooperates in releasing of virus progeny from infected cells both through the non-lytic mechanism during the early phase of infection [16] and the activation of cell apoptosis in later stages by interacting with mitochondrial ionic channels (VDAC2) [17].

IBDV serotype 1 is pathogenic to chickens but the virulence among this group can vary. The very virulent IBDV (vvIBDV) are the most pathogenic and can cause mortality up to $100 \%$ in SPF chickens. Classical and US variant strains are less virulent but they are immunosuppressive. The attenuated strains are generated by passaging different virus pathotypes on cell culture or SPF chicken embryos resulting in loss of pathogenic capacity [1]. Such strains are used in commercial live vaccines.

IBD has been reported in Poland since the end of the 1970s when the first epidemic caused by classical strains occurred. At the end of 1991, the first cases of acute IBDV were diagnosed. Infections with very virulent 
IBDV have caused economic losses due to high mortality rates. Afterwards, new immunoprophylaxis programmes were implemented which reduced the number of vvIBDV infections, but nevertheless IBD was still affecting polish poultry production [18]. Some of the Polish classical and very virulent strains have been antigenically and molecularly characterized [19] but since then there has been a lack of information about the recent field IBD situation in this part of Europe.

The aim of this study was a genetic and pathotypic characterization of a reassortant IBD virus detected in Poland.

\section{Materials and methods Samples}

Samples were collected in 2003 from vaccinated broiler chickens (Nobilis D78, MSD Netherlands) with signs of immunosuppressive disorder. Ten bursa samples were collected for laboratory examinations. The tissue samples were homogenised in phosphate buffered saline $(4 \mathrm{~mL}$ PBS per gram tissue) and centrifuged at $4{ }^{\circ} \mathrm{C} 3500 \mathrm{~g}$ for $15 \mathrm{~min}$. The fluid obtained was collected and stored (below $-65^{\circ} \mathrm{C}$ ) for further investigations.

\section{Virus isolation}

The virus isolation was conducted on 10-day-old SPF embryonated eggs using the chorioallantoic membrane route (CAM) [20]. The fluid was filtered through a $0.45 \mu \mathrm{m}$ membrane before inoculation. After 7-day incubation the embryos and chorioallantoic membrane were harvested, homogenised and stored below $-65^{\circ} \mathrm{C}$.

\section{Detection and identification of IBDV}

The total RNA was extracted using an RNeasy Mini Kit (Qiagen, Germany) according to the manufacturer's instructions. The presence of the IBD virus in bursal and embryo-derived samples was confirmed with adherence to a previously published rRT-PCR protocol [21]. Identification of the IBDV genotype was performed according to a previously described RT-PCR aimed at the hypervariable domain of VP2 peptide [22]. The partial sequence of
VP1 peptide was amplified with primers designed to the nucleotide sequence of D6948 strain (GenBank Accession number AF240687, Table 1) which are complementary to the $5^{\prime}$ two-thirds of segment $\mathrm{B}$. The RT-PCR reaction was performed in a $25 \mu \mathrm{L}$ volume of reaction mixture using the one-step RT-PCR kit (Qiagen, Germany). The reverse transcription step was conducted at $50{ }^{\circ} \mathrm{C}$ for $30 \mathrm{~min}$ and PCR was performed under the following conditions: initial denaturation at $95^{\circ} \mathrm{C}$ for $15 \mathrm{~min}$, followed by 35 cycles of amplification (denaturation $94{ }^{\circ} \mathrm{C}$ for $40 \mathrm{~s}$, annealing at $58{ }^{\circ} \mathrm{C}$ for $1 \mathrm{~min}$ and elongation at $72{ }^{\circ} \mathrm{C}$ for $1 \mathrm{~min}$ ). Final extension was conducted at $72{ }^{\circ} \mathrm{C}$ for $7 \mathrm{~min}$. The PCR products obtained were sequenced in both directions by a commercial service (Genomed, Poland).

\section{Nucleotide sequence and analysis}

Molecular characterization and phylogenetic analysis was performed in MEGA 6 [23]. The nucleotide and amino acid sequences were aligned with the ClustalW algorithm. Phylogenetic trees were constructed using the neighbour-joining method with 1000 replicates. A bootstrap value over 70 was considered reliable for the tree topology.

\section{Full-length sequencing of genomic segments by high-throughput sequencing}

The IBDV virus suspension was centrifuged at $3500 \mathrm{~g}$ for 5 min at $4{ }^{\circ} \mathrm{C}$ and filtered through a $0.45 \mu \mathrm{m}$ membrane (Sartorius, Germany). For nuclease treatment $180 \mu \mathrm{L}$ of virus supernatant was incubated for $30 \mathrm{~min}$ at $37^{\circ} \mathrm{C}$ with the addition of 40 units of DNase I (Turbo DNase, Invitrogen, Lithuania) and 20 units of ribonuclease (RNase One, Promega, USA). Afterwards, TRI Reagent extraction of total RNA was conducted using a Direct-zol RNA MiniPrep Kit (Zymo Research, USA) according to the supplier's instructions. The eluted RNA was subsequently subjected to reverse transcription with the use of the SuperScript IV First-Strand Synthesis System (Invitrogen, Lithuania) and random primers.

The libraries were created using the Ilumina Nextera XT DNA Library Preparation Kit according to the

Table 1 Primer sequences used in this study for the amplification of a partial sequence of VP1 gene

\begin{tabular}{lll}
\hline Primer & Sequence $\left(\mathbf{5}^{\prime} \rightarrow \mathbf{3}^{\prime}\right)$ & $\begin{array}{l}\text { Nucleotide position according to D6948 } \\
\text { strain (AF240687) }\end{array}$ \\
\hline SB1F & $\begin{array}{l}\text { Size } \\
\text { of amplicon } \\
(\mathbf{b p})\end{array}$ \\
SB1R & GTGGAAGAACTCCTGATCCCTAA & $193-215$ \\
SB2F & GATGGAGCTGACCATATGTT & $1117-1136$ \\
SB2R & AACAAGAAGAAGCTGCTCAGC & $1006-1026$ \\
\hline
\end{tabular}


manufacturer's protocol and afterwards were sequenced using the MiSeq System (Ilumina, USA) with $2 \times 300$ paired-end reads. The sequences obtained were first mapped using BLAST analysis with the NCBI database in order to remove host-derived sequences (Gallus gallus). The remaining sequences were de novo assembled into contigs using the SPAdes genome assembler (version 3.11.1) [24].

\section{Pathogenicity in chickens}

Animal experiments were carried out in accordance with the requirements and authorization of the local ethical commission (Permit no. 87/2012). The D78 (Nobilis, Intervet, Netherlands) and $75 / 11$ were used as a reference for attenuated and typical very virulent strains. Before the animal trial, the $75 / 11$ strain was characterised genetically (partial sequence of VP2: KX759595 and VP1: KX759549) and pathotypically (60\% mortality in 5-week old SPF chickens). Based on the OIE standards [20], it was classified as vvIBDV (data not published). Forty fiveweek-old SPF-layers (White Leghorn, Valo BioMedia, Germany) were divided into 4 groups (10 birds/group). Birds from groups 1 and 2 were intraocularly inoculated with $10^{4} \mathrm{EID}_{50} / 0.1 \mathrm{~mL}$ of Bpop/03 virus suspension (the reassortant strain) and 75/11 virus (vvIBDV strain), respectively. Chickens from group 3 were inoculated with 1 dose of vaccine D78 strain (attenuated IBDV control) and the 4th group was given saline buffer and served as a normal control group. Birds were housed in HEPAfiltered isolators (Montair Andersen B.V., Holland) for 10 days. All chickens were observed daily. All dead or euthanized birds were examined at necropsy and the bursae of Fabricius (BF) were taken for further analysis (histopathology, molecular characterisation, and calculation of bursa to bodyweight (B-BW) index).

\section{Histopathology}

Half of each bursa was fixed in 10\% phosphate-buffered formalin. In further proceedings the tissues were embedded in paraffin, sectioned and stained using haematoxylin and eosin. The preparations were microscopically examined and evaluated for histopathological abnormalities according to the criteria described by Jackwood et al. [5].

\section{Statistical analysis}

The B-BW indexes obtained from each experimental group versus the control group were compared by means of the Mann-Whitney $U$ test, using the social science statistics on-line calculator [25]. To assess if differences in mortality between groups of chickens infected with typical and reassortant IBDV are statistically significant, the Chi square $\left(\chi^{2}\right)$ test was used. The results with $P<0.05$ were recognised as statistically significant.

\section{Identification of concomitant pathogens}

In order to reveal the presence of any concomitant pathogens, next-generation sequencing of extracted total DNA and RNA in Bpop/03 samples were performed. The total DNA was purified using a QIAamp DNA Mini kit (Qiagen, Germany) in accordance with the manufacturer's instructions. The purification of total RNA was described in the previous subsection.

\section{Results}

\section{Detection of IBDV}

The rRT-PCR reaction confirmed the presence of IBDV in the examined flock and the presence of virus in inoculated SPF embryos. Further identification with conventional RT-PCR, sequencing and BLAST searches of partial sequences of both segments revealed that the analysed VP2 gene sequence has high nucleotide identity to the very virulent D6948 strain (Accession Number AF240687) and VP1 gene sequence to the cell culture-adapted attenuated 903/78 strain (JQ411013).

\section{Sequence analysis}

The nearly-complete consensus genome sequence of the Bpop/03 isolate obtained by NGS technology was submitted to GenBank (Accession Numbers: segment A-MH545934, segment B-MH545935). The sequences were aligned using the BLAST tool with the NCBI database. Most of the available IBDV sequences were retrieved and used for further molecular analysis (listed in Table 2). The alignment of both segment sequences confirmed the reassortant nature of the Bpop/03 isolate. The comparison of segment A and B nucleotide sequences revealed $99.1 \%$ similarity to the European vvIBDV strain D6948 and $99.3 \%$ similarity to the attenuated strain 903/78.

The deduced amino acid sequence of segment A exhibited a profile typical for very virulent strains with the presence of four specific alterations-one each in the VP5 (F30) and VP2 proteins (L324) and two in VP3 (M778, I856) (Table 3). The first changed residue is located within the VP5 $\mathrm{N}$-terminal domain that is responsible for the interaction with voltage-dependent anion channel 2 (VDAC2) [17] but without further investigation it is difficult to anticipate its impact on the activation of cell apoptosis process. However, the presence of leucine residue at position 324 leads to a loss of IBDV binding capacity with Mab 8 [26]. Finally, the role of the two changes within VP3 protein in IBDV virulence is unknown. The VP1 protein sequence comprised amino acids characteristic for attenuated strains with only one change at position $24(\mathrm{~A} \rightarrow \mathrm{V})$ and there 
Table 2 List of IBDV's used in phylogenetic analysis

\begin{tabular}{|c|c|c|c|c|}
\hline \multirow[t]{2}{*}{ IBDV strain } & \multirow[t]{2}{*}{ Origin } & \multirow[t]{2}{*}{ Pathotype/serotype } & \multicolumn{2}{|c|}{ Accession number } \\
\hline & & & Segment A & Segment B \\
\hline 02015.1 & Venezuela & Reassortant & AJ879932 & AJ880090 \\
\hline 100056 & France & Reassortant & KU2345528 & KU2345529 \\
\hline $150124 / 1.1$ & Algeria & Reassortant & MF969105 & MF969106 \\
\hline $150144 / 5.1$ & Algeria & Reassortant & MF969115 & MF969116 \\
\hline $23 / 82$ & UK & Serotype 2 & AF362773 & AF362774 \\
\hline 88180 & Ivory Coast & Very virulent & AM111353 & AM111354 \\
\hline 89163 & France & Very virulent & HG974563 & HG974564 \\
\hline $903 / 78$ & Hungary & Attenuated & AF362773 & JQ411013 \\
\hline 9109 & USA & Classical & AY462027 & AY459321 \\
\hline 94432 & France & Very virulent & AM167550 & AM167551 \\
\hline BD 3/99 & Bangladesh & Very virulent & AF362770 & AF362776 \\
\hline CA-D495 & USA & Reassortant & JF907703 & JF907704 \\
\hline CA-K785 & USA & Reassortant & JF907702 & JF907705 \\
\hline Cro-lg/02 & Croatia & Very virulent & EU184685 & EU184686 \\
\hline $\mathrm{Cu}-1$ & Germany & Attenuated & D00867 & AF362775 \\
\hline D6948 & Netherlands & Very virulent & AF240686 & AF240687 \\
\hline D78 & Nobilis & Attenuated & AF499929 & EU162090 \\
\hline Edgar & USA & Classical & AY462026 & AY918949 \\
\hline Faragher 52/70 & UK & Classical & HG974565 & HG974566 \\
\hline GLS & USA & Variant & AY368653 & AY368654 \\
\hline Gt & China & Attenuated & DQ403248 & DQ403249 \\
\hline Gx & China & Reassortant & AY444873 & AY705393 \\
\hline GX-NN-L & China & Reassortant & JX134485 & JX134486 \\
\hline Harbin-1 & China & Reassortant & EF517528 & EF517529 \\
\hline HBDY-1 & China & Classical & KX592158 & KX592159 \\
\hline HK46 & China & Very virulent & AF092943 & AF092944 \\
\hline HLJ-0504 & China & Reassortant & GQ451330 & GQ451331 \\
\hline $\mathrm{HN}$ & China & Reasortant & KC109816 & KC109815 \\
\hline HuB-1 & China & Very virulent & KF589805 & GQ449693 \\
\hline HuN11 & China & Reassortant & LM651367 & LM651368 \\
\hline IBD13HeB01 & China & Reassortant & KP676467 & KP676468 \\
\hline Irwin Moulthrop & USA & Classical & AY029166 & AY029165 \\
\hline K669 & USA & Reassortant & JN585293 & JN411134 \\
\hline ks & Israel & Very virulent & DQ927042 & DQ927043 \\
\hline KZC-104 & Zambia & Reassortant & AB368968 & AB368969 \\
\hline Lukert & USA & Classical & AY918948 & AY918947 \\
\hline NB & China & Very virulent & EU595667 & EU595673 \\
\hline $\mathrm{OH}$ & USA & Serotype 2 & - & U20950 \\
\hline OKYM & Japan & Very virulent & D49706 & D49707 \\
\hline PA/00924/14 & USA & Serotype 2 & KP642112 & KP642111 \\
\hline SD10LY01 & China & Very virulent & KF569803 & KF569804 \\
\hline SH95 & China & Reassortant & AY134874 & AY134875 \\
\hline SH99 & China & Very virulent & LM651365 & LM651366 \\
\hline T09 & Nigeria & Very virulent & AY099456 & AY099457 \\
\hline Tasik & Indonesia & Very virulent & AF322444 & AF322445 \\
\hline TL2004 & China & Reasortant & DQ088175 & DQ118374 \\
\hline UK661 & UK & Very virulent & AJ318896 & AJ318897 \\
\hline UPM04/190 & Malaysia & Very virulent & KU958716 & KU958717 \\
\hline
\end{tabular}


Table 2 (continued)

\begin{tabular}{lllll}
\hline IBDV strain & Origin & Pathotype/serotype & & \multicolumn{2}{l}{ Accession number } \\
\cline { 4 - 5 } & & & Segment A & Segment B \\
\hline Variant E & USA & Variant & AF133904 & AF133905 \\
Winterfield 2512 & Cevac & Attenuated & - & AF083092 \\
ZJ2000 & China & Reassortant & AF321056 & DQ166818 \\
\hline
\end{tabular}

Table 3 Amino acid differences between typical vvIBDV (D6948, 89163), attenuated strain (D78) and Polish reassortant strain (Bpop/03)

\begin{tabular}{|c|c|c|c|c|c|c|c|c|c|c|c|c|c|c|c|c|c|c|c|c|c|c|c|c|c|c|}
\hline \multirow[b]{2}{*}{$\begin{array}{l}\text { IBDV } \\
\text { strain }\end{array}$} & \multirow[b]{2}{*}{ Phenotype } & \multicolumn{7}{|c|}{ VP5 } & \multicolumn{12}{|c|}{ VP2 } & \multicolumn{6}{|c|}{ VP4 } \\
\hline & & $\Xi$ & లి & 8 & $\pi$ & $\stackrel{\infty}{=}$ & $\stackrel{2}{=}$ & $\ddot{m}$ & $\tilde{\approx}$ & $\underset{\sim}{\mathcal{N}}$ & $\ddot{n}$ & $\stackrel{7}{7}$ & 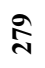 & 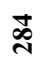 & ลे & ఫิ & ลे & ลे & त & ల্ল & $\sqrt{7}$ & in & $\mathscr{8}$ & 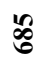 & $\frac{n}{1}$ & $\sqrt{n}$ \\
\hline $\begin{array}{c}\text { D6948 } \\
\text { AF240686 } \\
\end{array}$ & Very virulent & $\mathbf{E}$ & $\mathbf{S}$ & $\mathbf{R}$ & $\mathbf{F}$ & $\mathbf{H}$ & $\mathbf{P}$ & W & $\mathbf{A}$ & I & $\mathbf{Q}$ & I & D & $\mathbf{A}$ & M & $\mathbf{I}$ & $\mathbf{S}$ & $\mathbf{S}$ & $\mathbf{Q}$ & $\mathbf{S}$ & $\mathbf{L}$ & I & $\mathbf{Y}$ & $\mathbf{N}$ & $\mathbf{S}$ & D \\
\hline $\begin{array}{c}\mathbf{8 9 1 6 3} \\
\text { HG974563 }\end{array}$ & Very virulent & . & $\cdot$ & $\cdot$ & $\cdot$ & $\mathbf{Y}$ & $\cdot$ & $\cdot$ & - & $\cdot$ & $\cdot$ & $\cdot$ & . & $\cdot$ & · & $\cdot$ & $\cdot$ & $\cdot$ & $\cdot$ & $\cdot$ & $\cdot$ & • & $\cdot$ & $\cdot$ & $\cdot$ & $\cdot$ \\
\hline $\begin{array}{r}\text { Bpop/03 } \\
\text { MH545934 } \\
\end{array}$ & Reassortant & . & $\mathbf{F}$ & $\cdot$ & . & $\cdot$ & $\cdot$ & - & $\cdot$ & $\cdot$ & $\cdot$ & . & - & $\cdot$ & - & $\cdot$ & . & $\cdot$ & $\mathbf{L}$ & $\cdot$ & $\cdot$ & . & . & $\cdot$ & . & · \\
\hline $\begin{array}{c}\text { D78 } \\
\text { AF499929 } \\
\end{array}$ & Attenuated & $\mathbf{K}$ & . & $\mathbf{G}$ & I & . & $\mathbf{S}$ & $\mathbf{R}$ & $\mathbf{P}$ & $\mathbf{V}$ & $\mathbf{H}$ & $\mathbf{V}$ & $\mathbf{N}$ & $\mathbf{T}$ & $\mathbf{L}$ & $\mathbf{L}$ & $\mathbf{N}$ & $\mathbf{N}$ & . & $\mathbf{R}$ & I & $\mathbf{V}$ & $\mathbf{C}$ & $\mathbf{K}$ & $\mathbf{P}$ & $\mathbf{H}$ \\
\hline & & & $\mathbf{V}$ & & & & & & & & & & & & VP1 & & & & & & & & & & & \\
\hline $\begin{array}{l}\text { IBDV } \\
\text { strain }\end{array}$ & Phenotype & $\stackrel{\infty}{\stackrel{\infty}{*}}$ & $\infty$ & $\bar{\infty}$ & $\stackrel{\circ}{\varrho}$ & $\nabla$ & 2 & ה & 5 & $\stackrel{10}{ \pm}$ & $\stackrel{0}{ \pm}$ & 于 & $\underset{\sim}{\mathcal{N}}$ & $\stackrel{m}{\sim}$ & 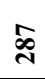 & बి & ले & $\stackrel{\infty}{\circ}$ & $\bar{n}$ & in & ช్ర & fâ & $\stackrel{\infty}{0}$ & ô & & \\
\hline $\begin{array}{c}\text { D6948 } \\
\text { AF240686 } \\
\end{array}$ & Very virulent & $\mathbf{V}$ & $\mathbf{T}$ & $\mathbf{P}$ & $\mathbf{A}$ & $\mathbf{V}$ & $\mathbf{K}$ & $\mathbf{A}$ & I & $\mathbf{T}$ & D & $\mathbf{N}$ & $\mathbf{E}$ & $\mathbf{F}$ & $\mathbf{A}$ & M & D & $\mathbf{K}$ & $\mathbf{S}$ & $\mathbf{P}$ & $\mathbf{P}$ & $\mathbf{S}$ & $\mathbf{P}$ & $\mathbf{R}$ & & \\
\hline $\begin{array}{c}\mathbf{8 9 1 6 3} \\
\text { HG974563 } \\
\end{array}$ & Very virulent & • & $\cdot$ & $\cdot$ & • & $\cdot$ & $\cdot$ & $\cdot$ & • & $\cdot$ & $\cdot$ & $\cdot$ & $\cdot$ & $\mathbf{Y}$ & . & $\cdot$ & $\cdot$ & $\cdot$ & $\cdot$ & $\cdot$ & $\cdot$ & $\cdot$ & $\cdot$ & $\cdot$ & & \\
\hline $\begin{array}{c}\text { Bpop/03 } \\
\text { MH545935 } \\
\end{array}$ & Reassortant & M & I & $\cdot$ & . & I & $\mathbf{T}$ & $\mathbf{V}$ & $\mathbf{V}$ & $\mathbf{N}$ & $\mathbf{E}$ & G & D & . & $\mathbf{T}$ & $\mathbf{L}$ & $\mathbf{E}$ & $\mathbf{R}$ & $\mathbf{R}$ & $\mathbf{L}$ & $\mathbf{S}$ & $\mathbf{G}$ & $\mathbf{S}$ & $\mathbf{K}$ & & \\
\hline $\begin{array}{c}\text { D78 } \\
\text { AF499929 }\end{array}$ & Attenuated & $\cdot$ & $\cdot$ & $\mathbf{L}$ & $\mathbf{T}$ & I & $\mathbf{T}$ & . & $\mathbf{V}$ & $\mathbf{N}$ & $\mathbf{E}$ & G & D & . & $\mathbf{T}$ & $\mathbf{L}$ & $\mathbf{E}$ & $\mathbf{R}$ & $\mathbf{R}$ & $\mathbf{L}$ & $\mathbf{S}$ & G & $\mathbf{S}$ & $\mathbf{K}$ & & \\
\hline
\end{tabular}

The deduced amino acid sequence of D6948 was used as a reference. Amino acid residues identical to reference strain were indicated by dots (.).

is no information about the function of this region of VP1 in viral replication.

The phylogenetic analysis also confirmed the different origins of both segment sequences. Based on the sequences of segment $A$, the 51 representatives of different geno- and serotypes of IBDV were clustered into three distinct branches designated as (i) serotype 2, (ii) very virulent and (iii) classical, variant and attenuated IBDV (Figure 1A). The Bpop/03 was found to be closely related to typical vvIBDV strains originating in Europe (D6948, 89163 and UK661) and Asia (TASIK, Gx and OKYM). However the phylogenetic tree of segment $B$ revealed that Bpop/03 formed a cluster with classical, variant and attenuated strains. Moreover the studied isolate was clustered on one branch with attenuated strains such as Winterfield 2512, Cu-1 and D78 (100\% bootstrap).

\section{Pathogenicity}

The infection of SPF chickens revealed the high pathogenicity of the Bpop/03 strain: 8 out of 10 SPF chickens died between 3 and 9 days post-infection (dpi). From the second day onwards, typical signs of IBD were observed, including ruffled feathers, depression and watery diarrhea. At necropsy, ecchymotic haemorrhages in the enlarged bursa of Fabricius, breast and thigh muscles and at the mucosal lining of the proventriculus, swollen spleens with punctate clusters of lymphoid tissue and swollen kidneys with visible tubule structure were observed (Figure 2). The bursae of chickens that died between 3 and 6 dpi were enlarged but on the 9th and 10th dpi the organ exhibited severe atrophy. Mortality in the control group inoculated with the reference very virulent IBDV reached $60 \%$ and chickens exhibited macroscopic lesions similar to those observed for 


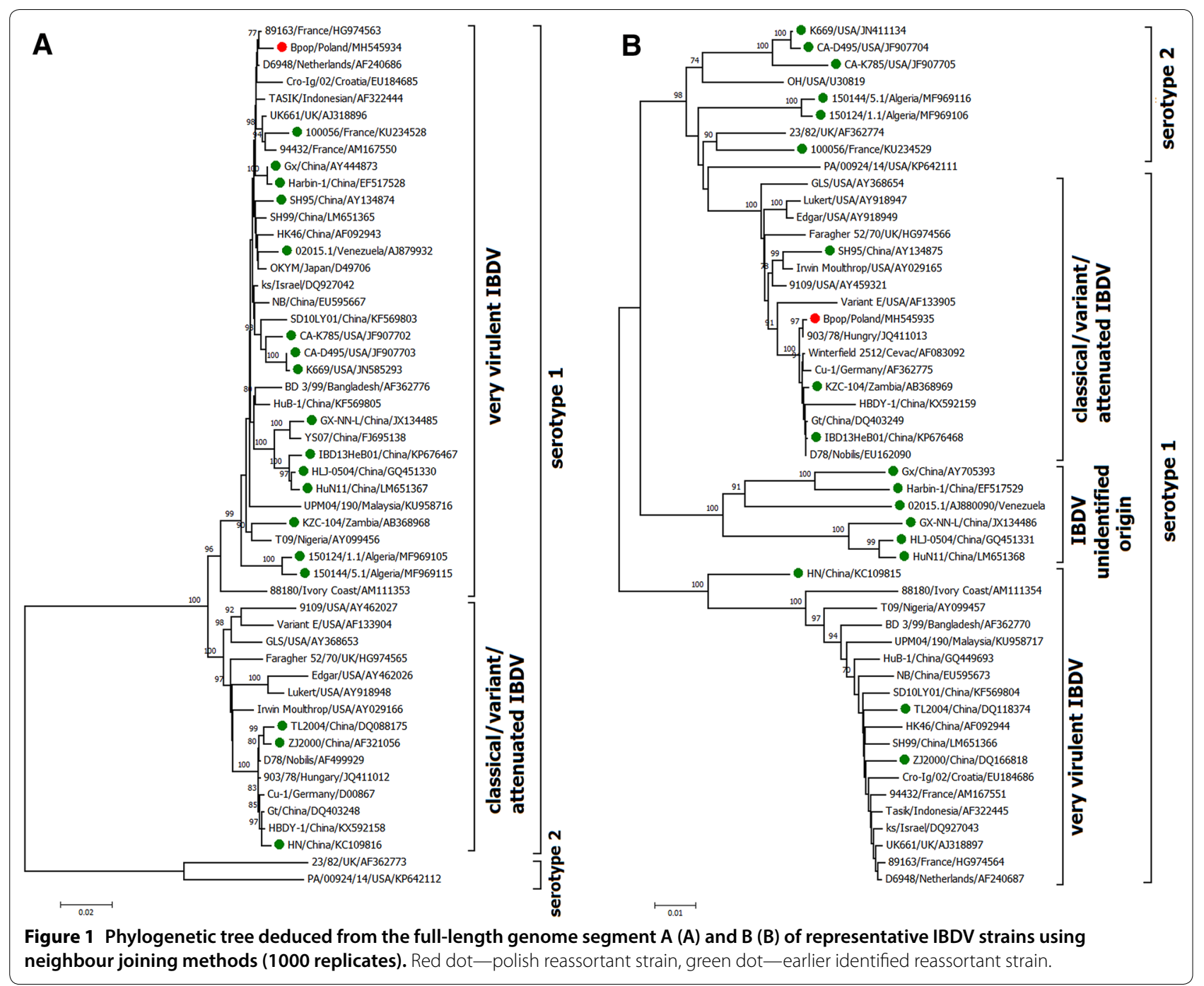

the Bpop/03 strain. The differences in mortality rates as well as in B-BW ratios at days 9 and 10 post-infection between groups of chickens infected with Bpop/03 and $75 / 11$ IBDV were not statistically significant. In contrast, $\mathrm{B}-\mathrm{BW}$ indexes of both of these groups were found to be statistically significantly lower than those of the normal and D78 control groups $(P<0.05)$. No clinical symptoms or gross bursal lesions were observed in the D78 and normal control groups. Detailed results of the pathogenicity experiment conducted are presented in Table 4. Moreover the de novo next-generation sequencing showed the absence of any concomitant bacteria or virus in the investigated samples.

\section{Histopathology}

Histopathological examination of the collected bursae of Fabricius from groups 1-3 indicated differences in the severity of microscopic lesions. The group inoculated with the vaccine D78 strain mainly caused low and moderate depletion of lymphatic follicles and hyperplasia of the tunica muscularis (Figure 3B). Bursa tissues microscopic alterations in groups challenged with Bpop/03 and 75/11 had a similar intensity. In birds found dead in the early phase of infection the lesions were mainly associated with the infiltration of inflammatory cells (heterophils and macrophages) in the tunica muscularis and interstitial connective tissue and depletion or necrosis of medullary and cortical regions 

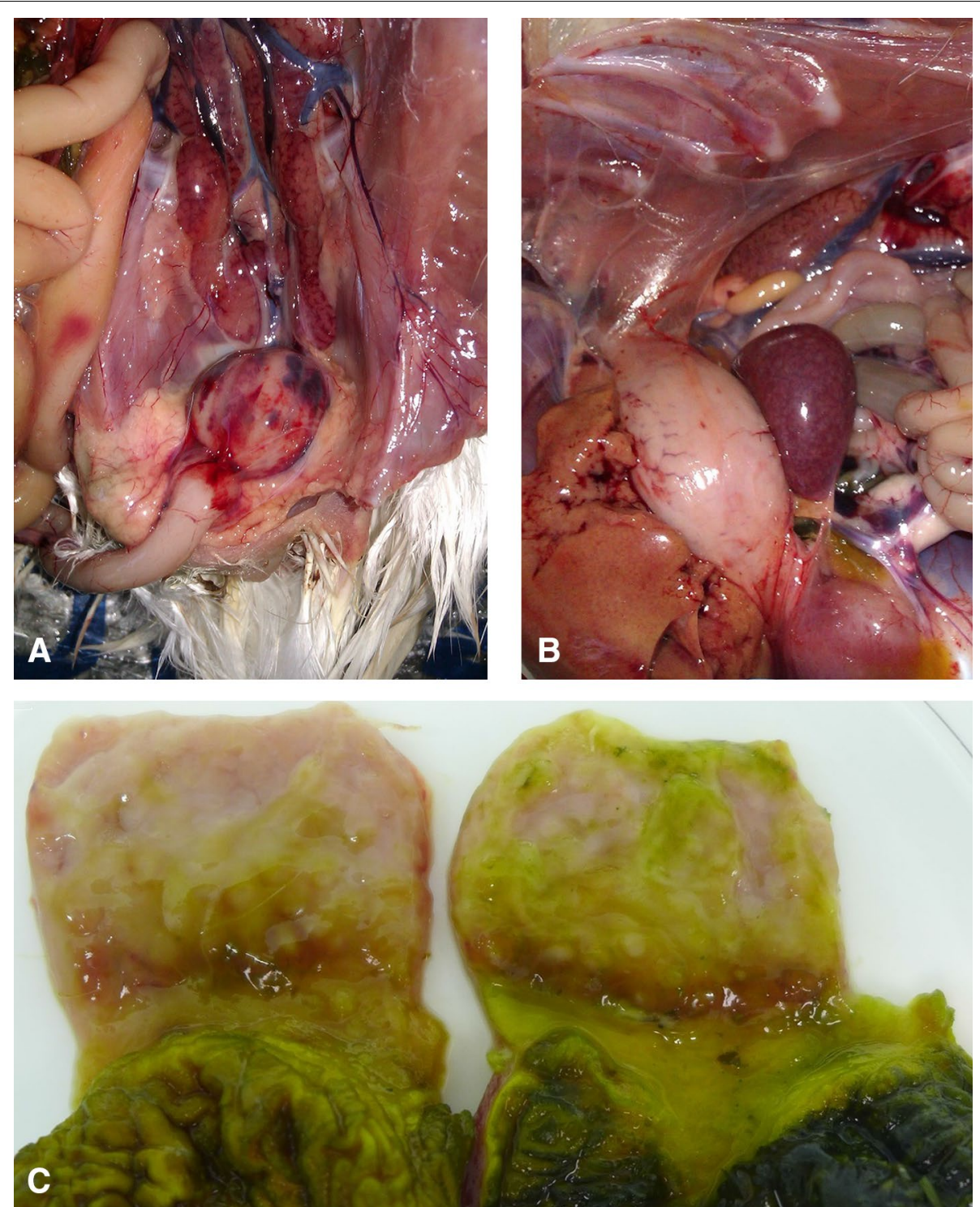

Figure 2 Macroscopic changes observed at necropsy in chickens infected with reassortant strain (Bpop/03). A Bursa of Fabricius and kidneys; B spleen; C proventriculus.

of the lymphatic follicles due to the degeneration of lymphoid cells (Figures $3 \mathrm{C}$ and E). On the contrary, the bursal tissue collected from euthanized birds was characterized by the absence of lymphoid follicles due to necrosis, atrophy or fibrosis (Figures 3D and F).

In the microscopic examination of the mock-inoculated control the normal histological structure of the $\mathrm{BF}$ was recorded (Figure 3A) and only two birds showed a slight loss of lymphoid cells in the medulla of the lymphatic follicles.

\section{Discussion}

Reassortment is one of the mechanisms of genetic diversity characteristic of viruses with segmented genomes. To emphasize the role of reassortment in virus genetic variability it is worth bringing up the example of influenza A virus, which each year brings new epidemiological threats 
Table 4 Results of in vivo IBDV virulence to SPF chickens

\begin{tabular}{|c|c|c|c|c|c|}
\hline \multirow[t]{2}{*}{ Group no. } & \multirow[t]{2}{*}{ IBDV strain } & \multirow[t]{2}{*}{ Mortality (\%) } & \multicolumn{2}{|c|}{$B-B W$ index $\bar{x} \pm S D$} & \multirow[t]{2}{*}{ Histopathologic lesion scores } \\
\hline & & & 3-5 dpi & $10 \mathrm{dpi}$ & \\
\hline 1 & Bpop/03 reassortant & $\begin{array}{l}8 / 10 \\
(80)\end{array}$ & $\begin{array}{l}4.53 \pm 1.97 \\
n=6\end{array}$ & $\begin{array}{l}1.43 \pm 0.61^{b} \\
n=4\end{array}$ & $4,4,4,4,4,4,4,4,4,4$ \\
\hline 2 & 75/11 vvIBDV control & $\begin{array}{l}6 / 10 \\
(60)\end{array}$ & $\begin{array}{l}5.73 \pm 1.77 \\
n=6\end{array}$ & $\begin{array}{l}1.45 \pm 0.21 \\
n=4\end{array}$ & $4,4,4,4,4,4,2,4,4,4$ \\
\hline 3 & D78 attenuated IBDV control & $\begin{array}{l}0 / 10 \\
(0)\end{array}$ & nd & $\begin{array}{l}3.45 \pm 1.09 \\
n=10\end{array}$ & $1,2,2,2,2,2,2,1,2,2$ \\
\hline 4 & Normal control & $\begin{array}{l}0 / 10 \\
(0)\end{array}$ & $\begin{array}{l}4.70 \pm 0.19^{a} \\
n=5\end{array}$ & $\begin{array}{l}5.44 \pm 0.29 \\
n=5\end{array}$ & $1,0,0,0,0,0,0,1,0,0$ \\
\hline
\end{tabular}

\footnotetext{
a From chickens euthanized at $3 \mathrm{dpi}$.

b From chickens dead at 9 dpi or euthanized at $10 \mathrm{dpi}$.

c According to Jackwood et al. [5], $\bar{x}$, arithmetic mean; SD: standard deviation; nd: not determined.
}

to humans and animals [27]. The first IBDV reassortants from Venezuela were reported over a dozen years ago [4], but since then more such reassortant viruses have been identified all over the world. The results of investigations mostly revealed the exchange of genome segments between different pathotypes representing viruses of serotype $1[1,2,6]$, but inter-serotype reassortants were also identified $[5,8]$.

The virulence of IBDV is a complex mechanism attributed to different components of the viral genome. Several mosaic IBDV constructed in vitro revealed the contribution of both segments A and B to virulence [28-31]. So far, most of the natural reassortant IBDV reported have exhibited intermediate virulence between very virulent and classical pathotype strains $[4,32]$.

To our knowledge, this study is the first report on the detection of new reassortant infectious bursal disease virus in Eastern Europe. Despite shuffling of genomic segments originating from two parental strains with distinct pathotypes (very virulent and classical cellculture adapted), the new IBDV strain has inherited high virulence and represents a very virulent phenotype based on the established in vivo criteria [20]. The Bpop/03 IBDV strain caused $80 \%$ mortality in SPF chickens (indicative of high virulence), the birds had typical signs of IBD and post-mortem examinations revealed macro- and microscopic abnormalities in multiple organs including extensive lesions in the bursa of Fabricius. The presence of concomitant pathogens was rejected in the face of results from de novo highthroughput sequencing. Moreover, high-throughput sequencing did not provide evidence of mixed infection with other IBDV and therefore we assume that the investigated virus is a natural very virulent/attenuated reassortant that has retained high virulence. New IBDV strains that have preserved their pathogenicity despite the reassortment have been recently described $[3,7]$. $\mathrm{Li}$ et al. [3] associated the preserved pathogenicity of the Chinese HLJ0504 strain with its novel segment B with unknown origin. Another two reassortants (150124 and 150244) from Algeria also exhibited comparable virulence to a very virulent reference strain (89163). In this case, the authors attributed the phenotype to the amino acid changes in the VP1 protein, but the fact is that both strains also possess several alterations of the VP5 protein that could modify its function. This part of the IBDV genome is quite conserved and plays a major role in IBDV virulence [33]. Sequence analysis of segment A of Bpop/03 revealed the presence of four unique residues within VP5 (F30), VP3 (M778, I856) and VP1 (V24). Because the molecular markers of IBDV virulence have not been defined, more investigations using reverse genetics are needed to explore the role of this mutation.

Despite the high nucleotide homology to the D78 strain $(99.1 \%)$, it is unlikely that segment B of the reassortant IBDV was derived from a commercial vaccine seed because the genetic changes are too extensive. Probably the vaccine strain had been circulating in the farm environment for a longer period before it reassorted with the very virulent field strain.

In conclusion, a new natural reassortant of very virulent IBDV was identified in Poland. The virus retained its high virulence despite the acquisition of a segment $B$ from the attenuated IBDV strain. This finding shows 

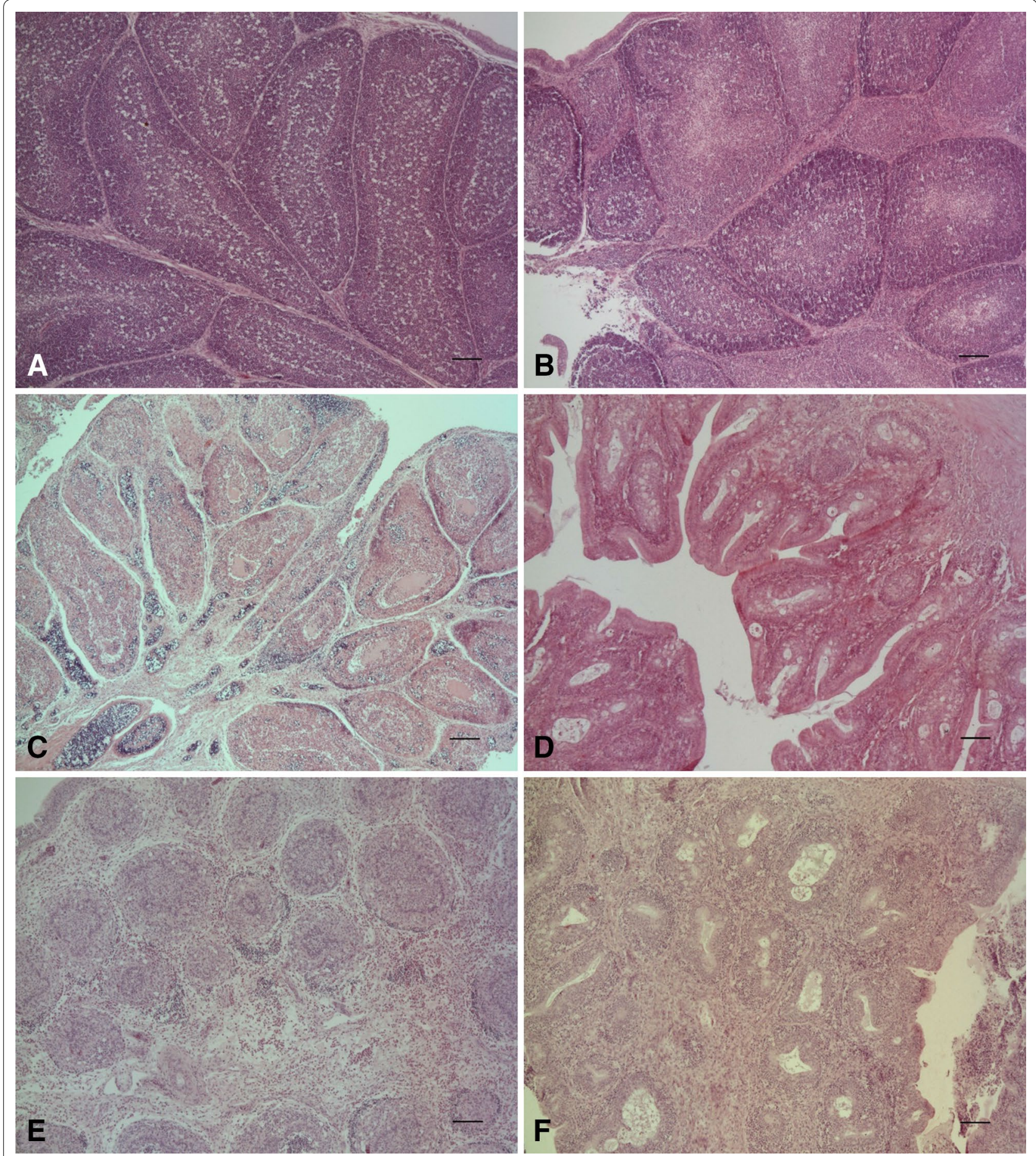

Figure 3 Differences in the severity of bursa of Fabricius macroscopic lesions in examined groups. A Normal group, B positive classic IBDV (D78) control group, C very virulent (75/11) control group at $3 \mathrm{dpi}$, D same group at $10 \mathrm{dpi}$, E Reassortant (Bpop/03) group at $3 \mathrm{dpi}$, and $\mathbf{F}$ same group at $10 \mathrm{dpi}$. The magnification is represented by the black band $(\times 50)$. 


\section{that the mechanism of IBDV virulence is intricate and merits further investigations.}

\begin{abstract}
Abbreviations
B-BW: bursa to bodyweight index; BF: bursae of fabricius; BLAST: basic local alignment search tool; $C A M$ : chorioallantoic membrane; $\mathrm{EID}_{50}$ : mean embryo infective dose; HEPA: high efficiency particulate air filter; IBD: infectious bursal disease; NGS: next generation sequencing; SPF: specific-pathogen-free; rRTPCR: real time RT-PCR; VVIBDV: very virulent infectious bursal disease virus.
\end{abstract}

\section{Competing interests}

The authors declare that they have no competing interests.

\section{Authors' contributions}

AP conceived the study. AP and AL participated in the laboratory examinations and conducted animal experiments. AJ performed histopathological analysis. AP, AL, AJ and KŚ participated in interpretation of the results. AP and KŚ participated in statistical analyses and contributed to the writing of the manuscript. All authors read and approved the final manuscript.

\section{Acknowledgements}

Authors are grateful to the employees of the Department of Omics Analysis, NVRI Puławy, for their help in high throughput sequencing results analysis.

\section{Availability of data and materials}

Genome sequences described in this manuscript are publicly available.

\section{Ethics approval and consent to participate}

This study and associated procedures were supervised and approved by the Local Ethical Commission in Lublin (Permit No. 87/2012) in agreement with the rules in place in the EU (Directive 2010/63/UE).

\section{Funding}

This work was partially funded by KNOW (Leading National Research Centre) Scientific Consortium "Healthy Animal - Safe Food", decision of Ministry of Science and Higher Education No. 05-1/KNOW2/2015.

\section{Author details}

1 Department of Poultry Diseases, National Veterinary Research Institute, Al. Partyzantow 57, 24-100 Pulawy, Poland. ${ }^{2}$ Department of Pathology, National Veterinary Research Institute, Al. Partyzantow 57, 24-100 Pulawy, Poland.

\section{Publisher's Note}

Springer Nature remains neutral with regard to jurisdictional claims in published maps and institutional affiliations.

Received: 30 June 2018 Accepted: 27 Auqust 2018

Published online: 12 September 2018

\section{References}

1. Eterradossi N, Saif YM (2013) Infections Bursal Disease. In: Swayne DE (ed) Diseases of Poultry, $13^{\text {th }}$ edn. Wiley-Blackwell, Ames

2. Wei Y, Yu X, Zheng J, Chu W, Xu H, Yu L (2008) Reassortant infectious bursal disease virus isolated in China. Virus Res 131:279-282

3. Li K, Courtillon C, Guionie O, Allée C, Amelot M, Qi X, Gao Y, Wang X, Eterradossi N (2015) Genetic, antigenic and pathogenic characterization of four infectious bursal disease virus isolates from China suggests continued evolution of very virulent viruses. Infect Genet Evol 30:120-127

4. Le Nouën C, Rivallan G, Toquin D, Darlu P, Morin Y, Beven V, Boisseson C, Cazaban C, Comte S, Gardin Y, Eterradossi N (2006) Very virulent infectious bursal disease virus: reduced pathogenicity in a rare natural segment-B reasserted isolate. J Gen Virol 87:209-216

5. Jackwood DJ, Sommer-Wagner SE, Crossley BM, Stoute ST, Woolcock PR, Charlton BR (2011) Identification and pathogenicity of a natural reassortant between a very virulent serotype 1 infectious bursal disease virus (IBDV) and a serotype 2 IBDV. Virology 420:98-105
6. Kasanga CJ, Yamaguchi T, Munan'andu HM, Ohya K, Fukushi H (2013) Genomic sequence of an infectious bursal disease virus isolate from Zambia: classical attenuated segment $B$ reassortment in nature with existing very virulent segment A. Arch Virol 158:685-689

7. Abed M, Soubies S, Courtillon C, Briand FX, Allée C, Amelot M, De Boisseson C, Lucas P, Blanchrd Y, Belahouel Kara R, Essalhi A, Temim S, Khelef D, Eterradossi N (2018) Infectious bursal disease in Algeria: detection of highly pathogenic reassortants viruses. Inf Genet Evol 60:48-57

8. Soubies MS, Courtilion C, Briand FX, Queguiner-Leroux M, Coutois D, Amelot M, Grousson K, Morillon P, Herin JB, Eterradossi N (2017) Identification of a European interserotypic reassortant strain of IBDV. Avian Pathol 46:19-27

9. Coulibaly F, Chevalier C, Gutsche I, Pous J, Navaza J, Bressanelli S, Delmas B, Rey FA (2005) The birnavirus crystal structure reveals structural relationships among icosahedral viruses. Cell 120:761-772

10. Fahey KJ, Erny K, Crooks J (1989) A conformational immunogen on VP2 of infectious bursal disease virus that induces virus-neutralizing antibodies that passively protect chickens. J Gen Virol 70:1473-1481

11. von Einem UI, Gorbalenya AE, Schirrmeier H, Behrens SE, Letzel T, Mundt E (2004) VP1 of infectious bursal disease virus is an RNA-dependent RNA polymerase. J Gen Virol 85:2221-2229

12. Tacken MG, Thomas AA, Peeters BP, Rottier PJ, Boot HJ (2004) VP1, the RNA-dependent RNA polymerase and genome-linked protein of infectious bursal disease virus, interacts with the carboxy-terminal domain of translational eukaryotic initiation factor 4All. Arch Virol 149:2245-2260

13. Luque D, Saugar I, Rejas MT, Carrascosa JL, Rodriguez JF, Castón JR (2009) Infectious bursal disease virus: ribonucleoprotein complexes of a doublestranded RNA virus. J Mol Biol 386:891-901

14. Hudson PJ, McKern NM, Power BE, Azad AA (1986) Genomic structure of the large RNA segment of infectious bursal disease virus. Nucleic Acids Res 14:5001-5012

15. Lejal N, da Costa B, Huet JC, Delmas B (2000) Role of Ser-652 and Lys-692 in the protease activity of infectious bursal disease virus VP4 and identification of its substrate cleavage sites. J Gen Virol 81:983-992

16. Méndez F, Romero N, Cubas LL, Delgui L, Rodríguez D, Rodríguez JF (2017) Non-lytic egression of infectious bursal disease virus (IBDV) particles from infected cells. PLoS ONE 12:e0170080

17. Li Z, Wang Y, Xue Y, Li X, Cao H, Zheng SJ (2012) Critical role for voltagedependent anion channel 2 in infectious bursal disease virus-induced apoptosis in host cells via interaction with VP5. J Virol 86:1328-1338

18. Minta Z, Daniel A (1994) Infectious bursal disease virus in Poland: Current situation and vaccinal control. In: Kaleta EF, Heffels-Redmann U, LangeHerbst H (eds). In: Proceedings of the International Symposium on Infectious Bursal Disease and Chicken Infectious Anaemia. Rauischholzhausen, June 1994. World Veterinary Poultry Association, pp 208-214

19. Domańska K, Mato T, Rivallan G, Śmietanka K, Minta Z, de Boisseson C, Toquin D, Lomniczi B, Palya V, Eterradossi N (2004) Antigenic and genetic diversity of early European isolates of Infectious bursal disease virus prior to the emergence of the very virulent viruses: early European epidemiology of Infectious bursal disease virus revisited? Arch Virol 149:465-480

20. World Organization for Animal Health (Office International des Epizooties) (2012) Infectious bursal disease. In: OIE manual of diagnostic tests and vaccines for terrestrial animals, $7^{\text {th }}$ ed. Paris

21. Wang Y, Qi X, Gao H, Gai Y, Lin H, Song X, Pei L, Wang X (2009) Comparative study of the replication of IBDV in DF-1 cell line and CEF evaluated by a new real-time RT-PCR. J Virol Methods 157:205-210

22. Pikuła A, Domańska-Blicharz K, Cepulis R, Śmietanka K (2017) Identification of infectious bursal disease virus with atypical VP2 amino acid profile in Latvia. J Vet Res 61:145-149

23. Tamura K, Stecher G, Peterson D, Filipski A, Kumar S (2013) MEGA6: molecular Evolutionary Genetics Analysis version 6.0. Mol Biol Evol 30:2725-2729

24. Nurk S, Bankevich A, Antipov D, Gurevich AA, Korobeynikov A, Lapidus A, Prijbelski AD, Pyshkin A, Sirotkin A, Sirotkin Y, Stepanauskas R, Clingenpeel SR, Woyke T, McLean JS, Lasken R, Tesler G, Alekseyev MA, Pevzner PA (2013) Assembling single-cell genomes and mini-metagenomes from chimeric MDA products. J Comput Biol 20:714-737

25. Social Science Statistics. https://www.socscistatistics.com/tests/Defau It.aspx. Accessed 6 Mar 2018

26. Eterradossi N, Arnauld C, Toquin D, Rivallan G (1998) Critical amino acid changes in VP2 variable domain are associated with typical and atypical 
antigenicity in very virulent infectious bursal disease viruses. Arch Virol 143:1627-1636

27. McDonald SM, Nelson MI, Turner PE, Patton JT (2016) Reassortment in segmented RNA viruses: mechanism and outcomes. Nat Rev Microbiol $14: 448-460$

28. Boot HJ, ter Huurne AAHM, Hoekman AJW, Peeters BPH, Gielkens AL (2000) Rescue of very virulent and mosaic infectious bursal disease virus from cloned CDNA: VP2 is not the sole determinant of the very virulent phenotype. J Virol 74:6701-6711

29. Boot HJ, Hoekman AJW, Gielkens ALJ (2005) The enhanced virulence of very virulent infectious bursal disease virus is partly determined by its B-segment. Arch Virol 150:137-144

30. Le Nouën C, Toquin D, Muller H, Raue R, Kean KM, Langlois P, Cherbonnel M, Eterradossi N (2012) Different domains of RNA polymerase of infectious bursal disease virus contribute to virulence. PLoS One 7:e28064
31. Escaffre $\mathrm{O}$, Le Nouën $C$, Amelot M, Ambroggio X, Ogden KM, Guionie O, Toquin D, Muller H, Islam MR, Eterradossi N (2013) Both genome segments contribute to the pathogenicity of very virulent infectious bursal disease virus. J Virol 87:2767-2780

32. Lu Z, Zhang L, Wang N, Chen Y, Gao L, Wang Y, Gao H, Li K, Qi X, Wang X (2015) Naturally occurring reassortant infectious bursal disease virus in northern China. Virus Res 203:92-95

33. Yao K, Goodwin MA, Vakharia VN (1998) Generation of a mutant infectious bursal disease virus that does not cause bursal lesions. J Virol 71:5647-5651
Ready to submit your research? Choose BMC and benefit from:

- fast, convenient online submission

- thorough peer review by experienced researchers in your field

- rapid publication on acceptance

- support for research data, including large and complex data types

- gold Open Access which fosters wider collaboration and increased citations

- maximum visibility for your research: over 100M website views per year

At BMC, research is always in progress.

Learn more biomedcentral.com/submissions 